\title{
Microbiological Investigation of Ready-to-cook Pork Bulgogi on Korean Markets
}

\author{
Sin Hye Ahn, Yong Ju Lee, Joo-Yeon Lee ${ }^{1}$, and Hyun-Dong Paik* \\ Division of Animal Life Science and Bio/Molecular Informatics Center, Konkuk University, Seoul 143-701, Korea \\ ${ }^{1}$ Korea Livestock Products HACCP Accreditation Service, Anyang 430-821, Korea
}

\begin{abstract}
In this study, ready-to-cook (RTC) pork bulgogi was investigated microbiologically to determine contamination levels. The investigation was conducted because of an increasing trend in the consumption of RTC meat products in Korea. Ninety marinated RTC pork bulgogi samples were collected from major retail outlets (M), department stores (D), and local markets (L) in Seoul, Korea from March to June 2011. This study examined total plate counts (TPC), Escherichia coli, and coliform bacterial counts, and the presence of Bacillus cereus, Staphylococcus aureus, Listeria monocytogenes, Salmonella spp., and E. coli O157:H7. The mean TPC values were 5.89, 6.08, and 5.89 Log CFU/g for M, D, and L, respectively. E. coli was not detected in any sample, but coliforms were present in $72(80 \%)$ of the 90 samples collected. B. cereus, E. coli O157:H7, and Salmonella spp. were not detected; however, S. aureus and L. monocytogenes were detected in five (5.5\%) and one (1.1\%) of the 90 samples. Samples collected from M and D were contaminated with $S$. aureus and those from L with L. monocytogenes. These results demonstrate that the conditions under which RTC pork bulgogis are handled and processed are unsanitary.
\end{abstract}

Key words: pork Bulgogi, ready-to-cook food, microbial safety, pathogens, Staphylococcus aureus, Listeria monocytogenes

\section{Introduction}

Pork bulgogi is a traditional Korean food. Thin slices of pork, usually arm picnic, shank, or ham, are marinated in a sauce containing soy sauce, onion, garlic, sesame oil and other seasonings. Pork bulgogi products can be contaminated with pathogenic bacteria during the handling or process if the raw materials used are contaminated or unhygienic conditions are applied. The ready-to-cook (RTC) product industry has expanded in Korea because of changes in customer consumption patterns. In Recent years, bulgogi is usually sold in markets as a RTC product. RTC foods, including bulgogi, are displayed open and exposed to contamination by bacterial pathogens; thus, several food-borne disease outbreaks have been associated with the consumption of contaminated RTC foods (Jo et al., 2003). Consumers find RTC products very convenient because these products only require heating to prepare a meal. However, the safety of these prod-

\footnotetext{
*Corresponding author: Hyun-Dong Paik, Division of Animal Life Science and Bio/Molecular Informatics Center, Konkuk University, Seoul 143-701, Korea. Tel: 82-2-2049-6011, Fax: 82-2-455-3082, E-mail: hdpaik@konkuk.ac.kr
}

ucts during distribution and sale is frequently not monitored, and RTC bulgogi, in particular, is exposed to a serious risk of contamination or spoilage by bacteria in the ingredients, such as vegetables, soy sauce, and raw meat (Beuchat, 1996; Nguyen-the and Carlin, 1994). The number of cases of food-borne disease caused by the consumption of contaminated RTC food has been increasing. In 2010, 271 cases of food poisoning were reported, and 7,218 cases of food poisoning have been reported in Korea. The most frequent causes of bacterial food poisoning in Korea are contamination with pathogens such as Escherichia coli (28 cases), Salmonella spp. (27 cases) and Staphylococcus aureus (19 cases) (KFDA, 2010a).

E. coli strains rarely cause disease, except certain strains involved in infections of the intestinal and urinary tracts of humans. Pathogenic E. coli can be divided into six pathotypes: enterohemorrhagic (EHEC), enterotoxigenic (ETEC), enteropathogeninc (EPEC), enteroaggregative (EAEC), enteroinvasive (EIEC), and diffusely adherent (DAEC). Pathogenic E. coli has become a significant health concern especially E. coli $\mathrm{O} 157: \mathrm{H} 7$, having caused major outbreaks in food (Watterworth et al., 2005).

$S$. aureus has been recognized as an indicator of food hygiene. S. aureus is a public health concern because of 
its ability to produce enterotoxins and grow in highly saline environments. In cured meats, such as cured ham, which have a high $\mathrm{pH}$, the water activity $\left(\mathrm{a}_{\mathrm{w}}\right)$ should be below 0.90 for preventing the production of staphylococcal enterotoxin (Gillespie, 2007; Gormley et al., 2010).

Salmonella spp. are the most common pathogens associated with food-borne diseases, typhoid fever in humans, self-limiting enteritis, and fatal infections in animals. Red meat and poultry are good sources of Salmonella.

In addition, improper process and equipment could be associated with increasing the probability of cross contamination with B. cereus and L. monocytogenes. B. cereus, a facultative anaerobic, spore-forming, motile bacterium has been identified as the causative agent of 2 types of gastrointestinal diseases (Ankolekar et al., 2009) and has been isolated from a wide variety of foods including spices (Choo et al., 2007; Konuma et al., 1988), ready-toserve foods (Harmon and Kautter, 1991), and meat products (Smith et al., 2004).

Listeria spp., particularly Listeria monocytogenes have been recognized as animal pathogens for over 70 years (Suihko et al., 2002; Wesley, 1999). In the 1990s, L. monocytogenes was frequently isolated from all the major food products, such as unfermented dairy products (Ryser, 1999), cheese and meat products (Farber and Peterkin, 1999), and poultry and egg products. L. monocytogenes can survive in vacuum and gas-packed products and grow at refrigerated temperatures; this is a cause of concern for chilled meat products with an extended shelf- life.

The objective of this research was to evaluate the level of contamination of RTC meat products with pathogens on the major Korean markets, such as major retail outlets, department stores, and local markets. Pork bulgogi was chosen as the target RTC meat product and then the microbiological condition was investigated with the food hygiene indicator, such as TPC, E. coli, and coliforms as well as the presence of pathogens, such as $B$. cereus, $E$. coli $\mathrm{O} 157: \mathrm{H7}$, S. aureus, Salmonella spp. and L. monocytogenes.

\section{Materials and Methods}

\section{Sample collection}

In total, 90 marinated pork bulgogi samples were collected from i.e., 3 samples each from 10 different major retail outlets (M), department stores (D), and local markets (L) located in Seoul, respectively, from March to June 2011 (Table 1). The collected samples were placed in sterile bags, transferred by refrigerated transport to the
Table 1. Types of samples used in this study

\begin{tabular}{lcc}
\hline \hline \multicolumn{1}{c}{ Location } & Number of places ${ }^{1)}$ & Number of samples \\
\hline Major retail outlet & 10 & 30 \\
Department store & 10 & 30 \\
Local market & 10 & 30 \\
\hline \multicolumn{1}{c}{ Total } & 30 & 90 \\
\hline
\end{tabular}

1) 3 samples were collected from each place.

laboratory, and processed within $24 \mathrm{~h}$ of collection.

\section{Food hygiene indicator bacteria}

Testing for indicator organisms (total plate counts, $E$. coli, and coliform bacterial counts) has been introduced as a simple means of assessing the hygiene status of foods and helps ensure food safety (Park, 2004). The experimental procedure in our study was developed on the basis of the Korea Food Code (KFDA, 2010b). A 1:10 dilution sample of pork bulgogi was prepared by adding $25 \mathrm{~g}$ of meat sample obtained from a location to $225 \mathrm{~mL} 0.1 \%(\mathrm{w} / \mathrm{v})$ peptone water; and the solution was homogenized in a stomacher (IUL instruments, Germany) for $2 \mathrm{~min}$. Total plated counts, and E. coli and coliform bacterial counts were quantitatively assessed by inoculating the diluted samples on tryptic soy agar (TSA) plates and petrifilms $\left(3 \mathrm{M}^{\mathrm{TM}}\right)$, respectively, and incubating $35^{\circ} \mathrm{C}$ for $24 \mathrm{~h}$.

\section{Isolation and characterization of pathogens B. cereus}

Twenty-five grams of meat samples obtained from each location was added to $225 \mathrm{~mL} 0.1 \%$ peptone water and homogenized for $1 \mathrm{~min}$. The mixed samples were inoculated on mannitol-egg yolk-polymyxin (MYP, Oxoid) agar and incubated at $35^{\circ} \mathrm{C}$ for $24 \mathrm{~h}$. We isolated the pinkred mannitol-negative colonies with surrounding lecithinase-positive zones of precipitation streak-cultured the isolated colonies on TSA plated plates, and maintained these as pure cultures. The strains on the TSA plate cultures were then, analyzed biochemically by using API 50 CH strips (Biomériux, France).

\section{E. coli O157:H7}

Twenty-five grams of samples obtained from each location was added to $225 \mathrm{~mL}$ modified E. coli (mEC) medium with novobiocin as the antimicrobial supplement and incubated at $35^{\circ} \mathrm{C}$ for $24 \mathrm{~h}$. The mixture was homogenized in a stomacher and mixed thoroughly. Inoculum were streaked on MacConkey sorbitol agar without cefixime and tellurite plates and incubated at $35^{\circ} \mathrm{C}$ for $16-$ 
$18 \mathrm{~h}$. The sorbitol-negative colonies were then subcultured on eosin methylene blue (EMB) agar plates. Distinct $E$. coli colonies were isolated and streaked onto TSA plates for further characterization. The colonies that showed a green metallic sheen on EMB agar, because of rapid lactose fermentation, were isolated and considered as those of E. coli. We performed $\mathrm{O} 157$ latex agglutination test (DR0620, Oxoid) (Stampi et al., 2004) for confirming the presence of E. coli $\mathrm{O} 157$ strains.

\section{S. aureus}

Twenty-five grams of samples, obtained from each location was added to $225 \mathrm{~mL}$ tryptic soy broth (TSB) with $10 \% \mathrm{NaCl}$ and enriched at $35^{\circ} \mathrm{C}$ for $24 \mathrm{~h}$ and then inoculated on Baird-Parker agar plates enriched with egg yolk (EY) tellurite. The plates were incubated under aerobic conditions at $35^{\circ} \mathrm{C}$ for $24 \mathrm{~h}$. Typical black and shiny convex-shaped colonies of $S$. aureus surrounded by clear zones of approximately $2-5 \mathrm{~mm}$ were isolated and cultured on TSA plates for further identification (Normanno et al., 2005). The presumed S. aureus colonies were examined by Gram staining and catalase test. Gram- and catalase-positive isolates were further identified using a latex agglutination kit (Pastorex ${ }^{\mathrm{TM}}$ Staph-Plus; Bio-Rad) and API Staph System (Biomériux).

\section{Salmonella spp.}

Twenty-five grams of meat samples obtained from each location was added to $225 \mathrm{~mL}$ buffered peptone water (BPW), incubated at $35^{\circ} \mathrm{C}$ for $24 \mathrm{~h}$, and homogenized for $1 \mathrm{~min}$ a stomacher. After pre-enrichment, $0.1 \mathrm{~mL}$ of the culture solution was added to $10 \mathrm{~mL}$ Rappaport-Vassiliadis (RV) broth. The RV broth was then incubated at $42^{\circ} \mathrm{C}$ for $18 \mathrm{~h}$. Loopfuls of the broth were streaked on Salmonella-Shigella (SS) agar and xylose lysine deoxycholate (XLD) agar plates. Red colonies with black centers on XLD agar were presumed as colonies of Salmonella spp. and were isolated and inoculated on TSA plates. Subsequently, the colonies were inoculated and streaked on triple sugar iron (TSI) slant. Because the inoculums could not ferment glucose and lactose, further study for gram staining, urease test and lysine decarboxylase test were not conducted.

\section{L. monocytogenes}

Twenty-five grams of meat samples obtained from each location was added to $225 \mathrm{~mL}$ Listeria enrichment broth (LEB) and incubated at $35^{\circ} \mathrm{C}$ for $18-24 \mathrm{~h}$. After incubation, the broth was homogenized and inocula were streaked on modified Oxford (MOX) agar plates with antimicrobial supplements and incubated at $37^{\circ} \mathrm{C}$ for 48 $\mathrm{h}$. The presumed colonies of $L$. monocytogenes were further confirmed and characterized. Morphologically typical colonies of L. monocytogenes were verified by Gram staining, catalase reaction, motility test, hemolysis on $5 \%$ sheep blood agar, CAMP test with S. aureus ATCC 25923, and fermentation of sugars by API Listeria (Biomériux) (Chaudhari et al., 2004).

\section{Statistical analysis}

Analysis of variance (ANOVA) was performed on all data with the general linear model (GLM) procedure by using the program Statistical Analysis System (SAS version 9.1). The bacterial total plate counts in colony forming units (CFU)/g were transformed to logarithmic values (Log CFU/g) for statistical analyses. Mean values were determined using Tukey's studentized range (HSD) tests.

\section{Results and Discussion}

\section{Distribution of food hygiene indicators in RTC pork bulgogi}

Detecting pathogenic bacteria in food is very important, but this involves a relatively complex procedure. Therefore, testing for indicator organism has been introduced as a simple means of assessing the hygiene status of food samples and helps ensure food safety. We assessed the hygiene status of pork bulgogi from major retail outlets, department stores, and local markets by collecting and analyzing 90 bulgogi samples (30 samples from each type of location).

Table 2 shows the microbial distribution in samples obtained from major retail outlets. The mean value of total plate counts for 3 samples obtained at a particular place (total, 10 places) in each of the location groups ranged from 4.59 to $7.07 \mathrm{Log} \mathrm{CFU} / \mathrm{g}$. Total coliforms detected in samples obtained from 6 out of 10 major retail outlets ranged from 1.00 to $4.09 \mathrm{Log}$ CFU/g. We observed similar coliform detection rates in samples obtained from department stores and local markets. Samples obtained from M3 (major retail outlets, place 3) showed the lowest total plate count and coliforms were not detected. However, samples obtained from M6 and M10 showed high total plate counts, even though the coliforms detected were 1.00 and $2.84 \mathrm{Log} \mathrm{CFU} / \mathrm{g}$, respectively. Samples obtained from the 10 department stores showed total plate counts and coliform counts ranging from 4.47 to 7.58 Log CFU/g and 2.23 to $4.25 \mathrm{Log}$ CFU/g, respectively. 
Table 2. Distribution of total plate counts, coliform, and $E$. coli counts in marinated meat from major retail outlets

\begin{tabular}{cccc}
\hline \hline \multirow{2}{*}{ Samples $^{1)}$} & \multicolumn{3}{c}{ Microbial count $^{2}$} \\
\cline { 2 - 4 } & TPC $^{3)}$ & Coliform & E. coli \\
\hline M1 & $5.57 \pm 0.04^{\text {bc }}$ & $2.51 \pm 0.30^{\mathrm{b}}$ & $\mathrm{ND}^{4)}$ \\
M2 & $5.19 \pm 0.16^{\mathrm{c}}$ & $1.38 \pm 1.08^{\mathrm{c}}$ & $\mathrm{ND}$ \\
M3 & $4.59 \pm 0.27^{\mathrm{d}}$ & $\mathrm{ND}^{\mathrm{d}}$ & $\mathrm{ND}$ \\
M4 & $5.97 \pm 0.10^{\mathrm{b}}$ & $1.30 \pm 1.42^{\mathrm{c}}$ & $\mathrm{ND}$ \\
M5 & $5.80 \pm 0.11^{\mathrm{b}}$ & $4.09 \pm 0.05^{\mathrm{a}}$ & $\mathrm{ND}$ \\
M6 & $7.07 \pm 0.54^{\mathrm{a}}$ & $1.00 \pm 1.10^{\mathrm{a}}$ & $\mathrm{ND}$ \\
M7 & $6.84 \pm 0.09^{\mathrm{a}}$ & $\mathrm{ND}^{\mathrm{d}}$ & $\mathrm{ND}$ \\
M8 & $5.28 \pm 0.15^{\mathrm{c}}$ & $\mathrm{ND}^{\mathrm{d}}$ & $\mathrm{ND}$ \\
M9 & $5.57 \pm 0.23^{\mathrm{bc}}$ & $\mathrm{ND}^{\mathrm{d}}$ & $\mathrm{ND}$ \\
M10 & $7.00 \pm 0.16^{\mathrm{a}}$ & $2.84 \pm 0.24^{\mathrm{b}}$ & $\mathrm{ND}$
\end{tabular}

${ }^{1)} \mathrm{M}$ : major retail outlet

${ }^{2)} \mathrm{Mean} \pm \mathrm{SD}(\mathrm{Log} \mathrm{CFU} / \mathrm{g})$ of samples

${ }^{3)} \mathrm{TPC}$ : total plate counts

${ }^{4)} \mathrm{ND}$ : not detected

${ }^{\mathrm{a}-\mathrm{d}}$ Means with different superscript within same row are significantly different $(p>0.05)$.

Samples obtained from L1 to L10 showed the mean values of total plate counts and coliforms ranging from 4.57 to 7.34 and 2.13 to $4.15 \mathrm{Log}$ CFU/g, respectively. E. coli were not detected in any samples. The total plate counts for most of the samples in our study were higher than that for raw meat. In the previous study, the counts of mesophilic microorganisms in raw pork meat ranged from $3.9 \times 10^{2}$ to $3.9 \times 10^{5} \mathrm{CFU} / \mathrm{g}$, and coliforms were not detected. The average number of aerobic mesophilic bacteria of marinated meat product was $2.3 \times 10^{8} \mathrm{CFU} / \mathrm{g}$, and the highest bacterial average was $3.1 \times 10^{8}$ (Björkroth, 2005). However, the study by Kwak et al. (1998) on pork bulgogi seasoning showed a high mesophilic total plate count of 5.97 Log CFU/g and a mean value of coliforms (logarithmic value for most probable number [MPN]/g) of $2.65 \mathrm{Log} \mathrm{MPN} / \mathrm{g}$. This result suggest that garlic, onion, soy sauce, and other ingredients in the seasoning used for pork bulgogi should have been the source of contamination and increased bacterial count.

The hygienic and sanitation level of 2 major retail outlets (M6 and M10), one department store (D6), and one local market was found to be low and should be improved. The hygiene status of marinated meat as observed by monitoring the indicator microorganisms, was significantly different among individual stores in each group $(p<0.05)$, even though the total plate counts and coliform counts were almost similar among the groups $(p>0.05)$.

\section{Isolation and characterization of pathogens}

Table 3. Distribution of total plate counts, coliform, and $E$. coli counts in marinated meat from department stores

\begin{tabular}{cccc}
\hline \hline \multirow{2}{*}{ Samples $^{1)}$} & \multicolumn{3}{c}{ Microbial count $^{2)}$} \\
\cline { 2 - 4 } & $\mathrm{TPC}^{3)}$ & Coliform & E. coli \\
\hline D1 & $6.90 \pm 0.05^{\mathrm{b}}$ & $3.62 \pm 0.05^{\mathrm{abcd}}$ & $\mathrm{ND}^{4)}$ \\
D2 & $5.83 \pm 0.15^{\mathrm{c}}$ & $\mathrm{ND}^{\mathrm{f}}$ & $\mathrm{ND}$ \\
D3 & $5.59 \pm 0.20^{\mathrm{c}}$ & $3.25 \pm 1.02^{\mathrm{cd}}$ & $\mathrm{ND}$ \\
D4 & $6.50 \pm 0.32^{\mathrm{b}}$ & $3.44 \pm 0.40 \mathrm{~b}^{\mathrm{cd}}$ & $\mathrm{ND}$ \\
D5 & $4.64 \pm 0.43^{\mathrm{d}}$ & $3.87 \pm 0.20^{\mathrm{abc}}$ & $\mathrm{ND}$ \\
D6 & $7.58 \pm 0.08^{\mathrm{a}}$ & $3.13 \pm 0.21^{\mathrm{d}}$ & $\mathrm{ND}$ \\
D7 & $4.47 \pm 0.07^{\mathrm{d}}$ & $4.25 \pm 0.07^{\mathrm{a}}$ & $\mathrm{ND}$ \\
D8 & $5.91 \pm 0.24^{\mathrm{c}}$ & $4.13 \pm 0.06^{\mathrm{ab}}$ & $\mathrm{ND}$ \\
D9 & $6.58 \pm 0.10^{\mathrm{b}}$ & $2.28 \pm 0.17^{\mathrm{e}}$ & $\mathrm{ND}$ \\
D10 & $6.83 \pm 0.06^{\mathrm{b}}$ & $3.30 \pm 0.13^{\mathrm{cd}}$ & $\mathrm{ND}$ \\
\hline
\end{tabular}

${ }^{1)} \mathrm{D}$ : department store

${ }^{2)} \mathrm{Mean} \pm \mathrm{SD}(\mathrm{Log} \mathrm{CFU} / \mathrm{g})$ of samples

${ }^{3)} \mathrm{TPC}$ : total plate counts

${ }^{4)} \mathrm{ND}$ : not detected

${ }^{\mathrm{a}-\mathrm{f}}$ Means with different superscript within same row are significantly different $(p>0.05)$.

Table 4. Distribution of total plate counts, coliform, and $E$. coli counts in marinated meat from local markets

\begin{tabular}{cccc}
\hline \hline \multirow{2}{*}{ Samples $^{1)}$} & \multicolumn{3}{c}{ Microbial count $^{2)}$} \\
\cline { 2 - 4 } & TPC $^{3)}$ & Coliform & E. coli \\
\hline L1 & $6.12 \pm 0.17^{\mathrm{bc}}$ & $3.53 \pm 0.08^{\mathrm{d}}$ & $\mathrm{ND}{ }^{4)}$ \\
L2 & $5.62 \pm 0.31^{\mathrm{d}}$ & $3.90 \pm 0.13^{\mathrm{abc}}$ & $\mathrm{ND}$ \\
L3 & $4.57 \pm 0.13^{\mathrm{e}}$ & $4.15 \pm 0.08^{\mathrm{a}}$ & $\mathrm{ND}$ \\
L4 & $4.87 \pm 0.09^{\mathrm{e}}$ & $2.13 \pm 0.32^{\mathrm{f}}$ & $\mathrm{ND}$ \\
L5 & $6.14 \pm 0.17^{\mathrm{bc}}$ & $\mathrm{ND}^{\mathrm{g}}$ & $\mathrm{ND}$ \\
L6 & $5.69 \pm 0.09^{\mathrm{d}}$ & $2.26 \pm 0.22^{\mathrm{f}}$ & $\mathrm{ND}$ \\
L7 & $6.09 \pm 0.04^{\mathrm{c}}$ & $3.03 \pm 0.26^{\mathrm{e}}$ & $\mathrm{ND}$ \\
L8 & $6.49 \pm 0.11^{\mathrm{b}}$ & $4.08 \pm 0.05^{\mathrm{ab}}$ & $\mathrm{ND}$ \\
L9 & $7.34 \pm 0.32^{\mathrm{a}}$ & $3.79 \pm 0.22^{\mathrm{bcd}}$ & $\mathrm{ND}$ \\
L10 & $6.16 \pm 0.02^{\mathrm{bc}}$ & $3.61 \pm 0.14^{\mathrm{cd}}$ & $\mathrm{ND}$ \\
\hline
\end{tabular}

${ }^{1)} \mathrm{L}$ : local market

${ }^{2)} \mathrm{Mean} \pm \mathrm{SD}(\mathrm{Log} \mathrm{CFU} / \mathrm{g})$ of samples

${ }^{3)} \mathrm{TPC}$ : total plate counts

${ }^{4)} \mathrm{ND}$ : not detected

${ }^{\mathrm{a}-\mathrm{g}}$ Means with different superscript within same row are significantly different $(p>0.05)$.

We evaluated the prevalence of selected bacterial pathogens (B. cereus, E. coli O157:H7, S. aureus, Salmonella spp., and L. monocytogenes) in marinated pork bulgogi collected from different types of retail shops located in Seoul, Korea. B. cereus, E. coli O157:H7, and Salmonella spp. were not detected in any samples (Table 5). We had two pink-red colonies with lecithinase-positive zones on the MYP agar, which were guessed as B. cereus, however, they were finally identified as $B$. subtilis according to their biochemical characterization found using API 50 $\mathrm{CH}$ strips. 
Table 5. Prevalence of food borne pathogens in marinated pork bulgogi

\begin{tabular}{cccccc}
\hline \hline \multirow{2}{*}{ Samples } & \multicolumn{5}{c}{ Food borne pathogens } \\
\cline { 2 - 6 } & B. cereus & E. coli O157:H7 & S. aureus & Salmonella spp. & L. monocytogenes \\
\hline Major retail outlet & $\mathrm{ND}^{1)}$ & $\mathrm{ND}$ & $4 / 30(13.3 \%)^{2)}$ & $\mathrm{ND}$ & $\mathrm{ND}$ \\
Department store & $\mathrm{ND}$ & $\mathrm{ND}$ & $1 / 30(3.3 \%)$ & $\mathrm{ND}$ & $\mathrm{ND}$ \\
Local market & $\mathrm{ND}$ & $\mathrm{ND}$ & $\mathrm{ND}$ & $\mathrm{ND}$ & $1 / 30(3.3 \%)$ \\
\hline Total & $\mathrm{ND}$ & $\mathrm{ND}$ & $5 / 90(5.6 \%)$ & $\mathrm{ND}$ & $1 / 90(1.1 \%)$ \\
\hline
\end{tabular}

${ }^{1)} \mathrm{ND}$ : not detected

${ }^{2)}$ Number of detected sample/total sample (\%)

Three colonies that showed a green metallic sheen on EMB agar were isolated and investigated for their O157 latex agglutination ability for the purpose of evaluating the presence of E. coli $\mathrm{O} 157$ strains. According to their incompetence of agglutination, the isolates were finally concluded not to be E. coli $\mathrm{O} 157: \mathrm{H} 7$.

The presumed colonies on XLD agar were isolated and inoculated on triple sugar iron (TSI) slants. After incubation, it was confirmed that these bacteria could metabolize glucose and lactose. The presence of these characteristics confirmed that the inoculums were not Salmonella spp. A previous study had reported a high prevalence rate (20\%) of Salmonella spp. in red meat from butcher shops in Gaborne, Botswana, which was attributed to inadequate temperature control, improper handling of raw meat, and inadequate environmental conditions (Mrema et al., 2006). However, no Salmonella spp. was isolated from pork bulgogi in our study.

Examining 90 pork bulgogi samples, 5 samples (5.6\%) tested were found to be positive for $S$. aureus. Four $(13.3 \%$ of 30$)$ of them were obtained from major retail outlets, and the remaining one (3.3\% of 30$)$ was obtained from a department store; none were detected in samples from local markets. In the previous studies, $S$. aureus has been isolated from several foods, including meat and meat products, chicken, milk and dairy products, fermented food items, vegetables, and fish products (Wieneke et al., 1993; Tamarapu et al., 2001). Salted food products, such as ham, have been reported to be responsible for about $24 \%$ of all cases of $S$. aureus food poisoning (Qi and Miller, 2000). Comparing the results of $S$. aureus in this study with those of other studies, the prevalence of $S$. aureus detected is very highly regarded. Normanno et al. (2005) suggested that coagulase-positive staphylococci and $S$. aureus were the most predominantly detected bacteria in various kind food products, e.g., $26.1 \%$ from fresh meat and $48.1 \%$ from other meat products.

\section{Characterization of isolated pathogens}

Tables 6 and 7 show the characteristics of isolated $S$. aureus and L. monocytogenes, respectively. Samples showing the presence of $S$. aureus were positive for coagulase,

Table 6. Morphological and biochemical characteristics of Staphylococcus aureus isolated from marinated pork bulgogi

\begin{tabular}{|c|c|c|c|}
\hline Characteristics & Results & Characteristics & Results \\
\hline Gram stain & $++^{1)}$ & D-Glucose & + \\
\hline Shape & Irregular clusters & D-Fructose & + \\
\hline Colony pigment (carotenoid) & + & D-Mannose & + \\
\hline Egg-yolk lecithinase & + & D-Maltose & + \\
\hline Catalase & + & D-Lactose & + \\
\hline Aerobic growth & + & D-Trehalose & + \\
\hline Growth on $10 \%(\mathrm{w} / \mathrm{v}) \mathrm{NaCl}$ broth & + & D-Mannitol & + \\
\hline Coagulase & + & Xylitol & $-2)$ \\
\hline Hemolysis & + & D-Melibiose & - \\
\hline Potassium nitrate & + & D-Raffinose & - \\
\hline$\beta$-Naphthyl phosphate & + & D-Xylose & - \\
\hline Sodium pyruvate (VP) & + & D-Saccharose & + \\
\hline L-Arginine & + & Methyl- $\alpha$-D-Glucopyranoside & - \\
\hline Urease & + & N-Acetyl-Glucosamine & + \\
\hline Acidification (aerobically) & & & \\
\hline
\end{tabular}

\footnotetext{
${ }^{1}$ Positive

${ }^{2)}$ Negative
} 
Table 7. Morphological and biochemical characteristics of Listeria monocytogenes isolated from marinated pork bulgogi

\begin{tabular}{|c|c|}
\hline Characteristics & Results \\
\hline Gram stain & $+^{1)}$ \\
\hline Shape & Rod \\
\hline Catalase & + \\
\hline Motility & + \\
\hline$\beta$-Hemolysis & + \\
\hline Differentiation L. innocua/L.monocytogenes & $-2)$ \\
\hline Esculin hydrolysis & + \\
\hline$\alpha$-Mannosidase & + \\
\hline \multicolumn{2}{|l|}{ Acidification } \\
\hline D-Arabitol & + \\
\hline D-Xylose & - \\
\hline L-Rhamnose & + \\
\hline Methyl- $\alpha$-D-glucopyranoside & + \\
\hline D-Ribose & - \\
\hline Flucose-1-phosphate & - \\
\hline D-Tagatose & - \\
\hline
\end{tabular}

${ }^{1)}$ Positive

${ }^{2)}$ Negative

catalase, and hemolysis tests and negative for fermentation of xylitol, D-melibiose, D-raffinose, D-xylose, and methyl- $\alpha$-D-glucopyranoside (Table 6). L. monocytogenes isolates hydrolyzed esculin on MOX agar and were positive for motility, $\alpha$-hemolysis, and CAMP tests. The isolates were identified with $98.6 \%$ accuracy on the basis of the results of the fermentation of sugars detected by using the API kit (Table 7). The pathogens were finally confirmed by $16 \mathrm{~S}$ rRNA gene sequencing and polymerase chain reaction (data not shown).

According to the Korea Livestock Products Sanitary Control Act, E. coli O157:H7 should not be detected in marinated meat. However, there are no specific standards for detecting food-borne pathogens in marinated meat. Therefore, microbial risk assessment should be strictly regulated and performed by evaluating the data scientifically.

\section{Acknowledgments}

This study was supported by Technology Development Program for Agriculture and Forestry (Project: 1110183), Ministry for Food, Agriculture, Forestry and Fisheries, Republic of Korea. This work was also supported by the Priority Research Centers Program through the National Research Foundation of Korea funded by the Ministry of Education, Science and Technology (2009-0093824).

\section{References}

1. Ankolekar, C., Rahmati, T., and Labbé, R. G. (2009) Detection of toxigenic Bacillus cereus and Bacillus thuringiensis spores in U. S. rice. Int. J. Food Microbiol. 128, 460-466.

2. Beuchat, L. R. (1996) Pathogenic microorganisms associated with fresh produce. J. Food Prot. 59, 204-216.

3. Björkroth, J. (2005) Microbiological ecology of marinated meat products. Meat Sci. 70, 477-480.

4. Chaudhari, S. P., Malik, S. V. S., Chatlod, L. R., and Barbuddhe, S. B. (2004) Isolation of pathogenic Listeria monocytogenes and detection of antibodies against phosphatidy linositolspecific phospholipase $\mathrm{C}$ in buffaloes. Comp. Immun. Microbiol. Infect. Dis. 27, 141-148.

5. Choo, E., Jang, S. S., Kim, K., Le, K. -G., Heu, S., and Ryu, S. (2007) Prevalence and genetic diversity of Bacillus cereus in dried red pepper in Korea. J. Food Prot. 70, 917-922.

6. Farber, J. M. and Peterkin, P. I. (1999) Incidence and behavior of Listeria monocytogenes in meat products. In: Listeria, listeriosis and food safety, 2nd ed. Marcel Dekker, Inc., NY, pp. 505-564.

7. Gillespie, I. A. (2007) Microbial agents of food poisoning and foodborne infection. In: Hobbs' food poisoning and food hygiene. McLauchlin, Jim, Little and Christine. (eds) 7th ed, Hodder Arnold, London, pp. 59-93.

8. Gormley, F. J., Little, C. L., Grant, K. A., Pinna, E., and McLauchlin, J. (2010) The microbiological safety of readyto-eat specialty meats from markets and specialty food shops: A UK wide study with a focus on Salmonella and Listeria monocytogenes. Food Microbiol. 27, 243-249.

9. Harmon, S. and Kautter, D. (1991) Incidence and growth potential of Bacillus cereus in ready-to-serve foods. J. Food Prot. 54, 372-374.

10. Jo, C., Han, C. H., Chung, K. H., and Byun, M. W. (2003) Gamma irradiation of ready-to-cook bulgogi improves safety and extends shelf-life without compromising organoleptic qualities. Nutraceut. Food 8, 191-195.

11. Konuma, H., Shinagawa, K., Tokumara, M., Onoue, Y., Konno, S., Fujino, N., Shigehisa, T., Kurata, H., Kuwabara, T., and Lopes, C. (1988) Occurrence of Bacillus cereus in meat products, raw meat and meat and meat product additives. J. Food Prot. 51, 324-326.

12. Korea Food and Drug Administration (2010a) The report of foodborne illness in Korea. Available from: http://e-stat. kfda. go.kr/

13. Korea Food and Drug Administration. Korea Food Code (2010b).

14. Ministry for Food, Agriculture, Forestry and Fisheries (2010) Korea livestock products sanitary control act.

15. Kwak, T. K., Moon, H. K., Park, H. W., Hong, W. S., Ryu, K., Chan H. J., Kim, S. H., and Choi, E. J. (1998) A quality assurance study for the application of cook/chill system in school foodservice operations (II) - Pork bulgogi (Broiled sliced pork with sauces)- J. Food Hyg. Safety 13, 319-331.

16. Mrema, N., Mpuchane, S., and Gashe, B. A. (2006) Prevalence of Salmonella in raw minced meat, raw fresh sausages and raw burger patties from retail outlets in Gaborne, 
Botswana. Food Control 17, 207-212.

17. Nguyen-the, C. and Carlin, F. (1994) The microbiology of minimally processed fresh fruits and vegetables. Crit. Rev. Food Sci. Nutr. 34, 370-401.

18. Normanno, G., Firinu, A., Virgilio, S., Nula, G., Dambrosio, A., Poggiu, A., Decastelli, L, Mioni, R., Scuota, S., Bolzoni, G., Di Giannatale, E., Salinetti, A. P., La Salandra, G., Bartoli, M., Zuccon, F., Pirino, T., Sias, S., Parisi, A., Quaglia, N. C., and Celano, G. V. (2005) Coagulase-positive Staphylococci and Staphylococcus aureus in food products marketed in Italy. Int. J. Food Microbiol. 98, 73-79.

19. Park, M. Y. (2004) Bacteriological survey for food/food contacting surfaces in large grocery stores in Korea. J. Fish. Sci. Tech., 7, 64-69.

20. Qi, Y. and Miller, K. J. (2000) Effect of low water activity on staphylococcal enterotoxin A and B biosynthesis. J. Food Prot. 63, 473-478.

21. Ryser, E. T. (1999) Incidence and behavior of Listeria monocytogenes in unfermented dairy products. In: Listeria, listeriosis and food safety, 2nd ed. Marcel Dekker, Inc., NY, pp. 359-409.

22. Smith, D. P., Errang, M. E., Feldner, P. W., Philips, R. W., and Meinersmann, R. J. (2004) Detection of Bacillus cereus on selected retail chicken products. J. Food Prot. 67. 17701773.
23. Suihko, M. -L., Salo, S., Miclasen, O., Gudbjörnsdóttir, B., Torkelsson G., Bredholt, S., Sjöberg, A., and Gustavsson, P. (2002) Characterization of Listeria monocytogenes isolates from the meat, poultry and seafood industries by automated ribotyping. Int. J. Food Microbiol. 72, 137-146.

24. Stampi, S., Caprioli, A., Luca, G. D., Quaglio, P., Sacchetti, R., and Zanetti, F. (2004) Detection of Escherichia coli O157 in bovine meat products in northern Italy. Int. J. Food Microbiol. 90, 257-262.

25. Tamarapu, S., McKillip, J. L., and Drake, M. (2001) Development of a multiplex polymerase chain reaction assay for detection and differentiation of Staphylococcus aureus in dairy products. J. Food Prot. 64, 664-668.

26. Watterwoth, L., Topp, E, Schraft, H., and Tin Leung, K. (2005) Multiplex PCR-DNA probe assay for the detection of pathogenic Escherichia coli. J. Microbiol. Meth. 60, 93-105.

27. Wieneke, A. A., Roberts, D., and Gilbert, R. J. (1993) Staphylococcal food poisoning in the United Kingdom. Epidmiol. Infect. 110, 519-531.

28. Wesley, I. V. (1999) Listeriosis in animals. In: Listeria, listeriosis and food safety. 2nd ed, Marcel Dekker, Inc., NY, pp 39-73.

(Received 2011.12.10/Revised 2012.7.16/Accepted 2012.8.14) 